\title{
TECHNOLOGIA I/A EDUKACJA
}

\author{
MiRosŁAW WoBALIS
}

\begin{abstract}
„Jesteśmy rzuceni na środek morza bez map i kompasów, boje zatonęły albo ich nie widać - mamy tylko dwie możliwości: cieszyć się z zapierających dech wizji nowych odkryć przed nami albo drżeć ze strachu przed zatonięciem. Natomiast szukanie azylu w bezpiecznym porcie jest pozbawione realnych podstaw; można pójść o zakład, że to, co dzisiaj wygląda na spokojną przystań, szybko zostanie unowocześnione...”
\end{abstract}

Zygmunt Bauman, Globalizacja

Dzieje relacji, wspólistnienia, symbiozy technologii i edukacji sięgają prapoczątków ludzkości. Trudno w tym miejscu jednoznacznie wyrokować czy pierwotnym dążeniem człowieka było „poznawać i uczyć” (siebie, drugiego), czy może „posługiwać się” czymś w jakimś celu (na przykład narzędziem). Jest jednak oczywiste, że u źródeł jednego i drugiego leży nadrzędna cecha naszego gatunku czyli ludzka, niczym nie skrępowana ciekawość oraz potrzeba komunikowania się. Ale czy tylko naszego gatunku? Ta sama cecha występuje przecież $\mathrm{u}$ naczelnych, a badania nad nią prowadzone są od lat. Szympansy uczą się od siebie, przekazują sobie wiedzę o narzędziach, naśladują umiejętności. Tych samych przymiotów można szukać również u dalszych „kuzynów” człowieka: ścierwnik biały, ptak z rodziny jastrzębiowatych, by pozyskać pożywienie rozbija kamieniami strusie jaja i muszle ostryg i umiejętność tę przekazuje młodym osobnikom $^{2}$. Jak widać, natura oparta jest na komunikowaniu i uczeniu się „W niej jako przestrzeni” oraz posługiwaniu się ,nią jako narzędziem”.

W poniższym tekście scharakteryzowane zostaną pokrótce relacje pomiędzy edukacją/nauką a technologią od czasów najdawniejszych do współczesnej nam 'Pangei komunikacyjnej'. Omówione zostaną ich główne wzajemne dodatnie

${ }^{1}$ Bauman Z. 2000. Globalizacja. Warszawa: Państwowy Instytut Wydawniczy. 101.

${ }^{2}$ Zob. Burni, D., B. Hoare, J. DiCostanzo i P. Benstead. 2009. Ptaki Encyklopedia. Warszawa: Wydawnictwo Naukowe PWN. 41. 
relacje, a następnie wskaże się zaburzenia komunikacyjne wpływające na te relacje ujemnie. Za przykład służyć będą trzy wybrane badania dotyczące mediów interaktywnych z ostatnich kilku lat.

U prapoczątków odkryć i wynalazków związanych z technikami przynależnymi zarówno procesom komunikowania się, jak i procesom dydaktycznym należą gesty, mowa i proste znaki graficzne. Pierwotne procesy komunikacji edukacyjnej wiążą się (zarówno u ludzi, jak i wspomnianych jastrzębiowatych) z dostrzeżeniem jakiegoś faktu, zjawiska czy prawidłowości i zapamiętaniu ich. W tym przypadku narzędziem obserwacji rzeczywistości są nasze zmysły, zaś mózg staje się narzędziem przełożenia tych jednostkowych „odkryć” na powtarzalne procesy. Pierwotne narzędzia komunikowania - pierwotne techniki informacyjne umożliwiały opisanie tych zjawisk językiem gestu, mowy lub znaku graficznego. Co istotne owe najprostsze i najbliższe człowiekowi technologie obrazowania, opisu i, z biegiem czasu, zapisu informacji pozostały niezmienione przez tysiące lat stając się podstawą naszej kultury i cywilizacji.

Do grupy pierwotnych technik ułatwiających przekazywanie mowy zaliczymy wszystkie środki ułatwiające zapamiętywanie: aliterację, rym, rytm. Te proste techniki do dzisiaj z powodzeniem wykorzystywane są w nauczaniu języków, gramatyki, ortografii, słownictwa. Historia rozwoju narzędzi komunikowania się jest walką człowieka o złamanie naturalnych ograniczeń czasu i przestrzeni. Mowa istnieje ,tu i teraz”, raz wybrzmiałe zdanie nigdy nie powróci w tej samej formie, a jego ulotny czas życia trwa tyle, ile czas wybrzmienia słów. Zapamiętane zdania żyć będą w pamięci osób i uczniów, które je usłyszały, a zarejestrowane frazy zawędrują tylko tam, dokąd dojdą nogi pamiętającego człowieka. Czas i przestrzeń istnienia komunikatu nierozerwalnie związane są $\mathrm{z}$ ciałem, przestrzenią i czasem. I w każdym przypadku z ograniczonym ich wymiarem. Największa rewolucja (choć biorąc pod uwagę czas i zasięg trwania - ewolucja) w technice, a później w technologiach komunikowania (a tym samym technologii kształcenia) odbyła się wraz z pojawieniem się pisma. Mowa zapisana w glinie, kamieniu czy na skórze stała się nieśmiertelna. Oderwała się od czasu, w którym powstała i swojej naturalnej przestrzeni pochodzenia. Pojawiły się wynalazki i narzędzia, dzięki którym słowa, znaki, liczby można było trwale przechowywać, przenosić oraz chronić. Powstały biblioteki, w których słowa się gromadzi, szkoły, w których słowa służyły zorganizowanej edukacji. Stworzono wreszcie archiwa gromadzące najważniejsze dla danej grupy ludności dokumenty piśmienne.

Mieszkańcom „Galaktyki Gutenberga”3 książka i wydrukowany tekst zdaje się narzędziem oczywistym i przynależnym cywilizacji człowieka od zawsze.

\footnotetext{
${ }^{3}$ McLuhan, M. 1962. Gutenberg galaxy: the making of typographic man. Toronto: University of Toronto Press. (Wydanie polskie: McLuhan, M. 2001. Galaktyka Gutenberga. W: McLuhan, E. i F. Zignore (red.). McLuhan. Wybór tekstów. Poznań: Zysk i S-ka).
} 
A jednak jest to tak młoda technologia w wymiarze ewolucji komunikacji, jak technologia druku 3D w ewolucji samego druku. Pismo liczy sobie ,tylko” około 7-8 tysięcy lat. „Nowoczesne” pismo fenickie o zmodyfikowanym alfabecie liczy sobie zaledwie 3000 lat $^{4}$. Kodeks jako zbiór kart złączonych na jednym z brzegów (zszytych, sklejonych) znany jest od końca I wieku n.e. Technologia druku w wersji europejskiej znana jest od 550 lat $^{5}$. Dla porównania przyjęto, że mowa wykształciła się 35-50 tysięcy lat temu' ${ }^{6}$.

Druk miał ogromny wpływ na masowe pojawienie się książek i, w związku z tym, łatwych w produkcji i dystrybucji podręczników. Druk przełamał ostatecznie elitarność tekstu, stając się narzędziem dostępnym powszechnie oraz, w sposób zasadniczy i nieodwracalny, zwiększając zasięg dotarcia oraz trwałość istnienia komunikatów. O ile można było nieodwracalnie zniszczyć rękopisy, a nawet spalić największą z bibliotek - aleksandryjski Bruchejon - to usunięcie 1000 identycznych kopii zadrukowanego maszynowo tekstu okazało się niewykonalne, o czym boleśnie przekonali się dyktatorzy w XX wieku. Książka stała się dobrem powszechnym i niezniszczalnym, zaś wiedza dostępna coraz szerszym kręgom odbiorców. Dzięki wynalazkowi druku i coraz doskonalszej technologii poligraficznej ( $w$ tym rozwijających się równolegle form dystrybucji i sprzedaży tekstu) dokonują się rewolucje religijne, obyczajowe, społeczne oraz edukacyjne. Druk zmniejszył radykalnie analfabetyzm, a postępujący egalitaryzm kształcenia i samokształcenia miał kluczowe znaczenie dla rewolucji naukowej, która wybucha wiek po pojawieniu się druku i trwa nieprzerwanie do dnia dzisiejszego. Pod wpływem lektury „Cierpień młodego Wertera” nieśmiertelnego Goethego młodzi ludzie masowo odbierają sobie życie, co prowokuje myślicieli XVIII i XIX wieku do stawiania pytań o rolę książki i jej destrukcyjny wpływ na psychikę młodych. W kolejnym wieku książki staną się jeszcze bardziej niebezpieczne i rewolucyjne, ,zatruwając" umysły nie tylko dzieci i młodzieży, ale i całych społeczeństw. XIX wiek przynosi kolejne, oczywiste w łańcuchu zdarzeń, technologie i narzędzia komunikacji oparte na wykorzystaniu sygnału elektrycznego, które bardzo szybko ewoluują, stając się kamieniami milowymi nowoczesnej cywilizacji technologicznej XX wieku. Technologie telegrafu, telefonii, radia oraz telewizji ostatecznie i bezpowrotnie łamią ograniczenia czasu, przestrzeni i dystansu w komunikowaniu się oraz nauczaniu. Od

\footnotetext{
${ }^{4}$ Vandendorpe, Ch. 1999. Du papyrus à l'hypertexte. Montreal: Éditions du Boréal. (Wydanie polskie: Vandendorpe, Ch. 2008. Od papirusu do hipertekstu. Esej o przemianach tekstu i lektury. Warszawa: Wydawnictwa Uniwersytetu Warszawskiego).

${ }^{5}$ Eskarpit, R. 1965. La révolution du livre. Paris: Presses Universitaires de France. (Wydanie polskie: Eskarpit, R. 1969/1991. Rewolucja ksiązki. Warszawa: PWN).

${ }^{6}$ Jest to sprawa wciąż dyskusyjna i stanowiąca żywy obszar badań: m.in. zdaniem prof. Shigeru Miyagawy z Massachusetts Institute of Technology do wykształcenia mowy, na skutek przypadkowej mutacji genetycznej, doszło około 80-50 tys. lat temu.
} 
pojawienia się telegrafu w 1837 roku do zaprezentowania pierwszych w pełni osobistych i powszechnie dostępnych komputerów z dostępem do globalnej sieci natychmiastowej komunikacji mija zaledwie $150 \mathrm{lat}^{7}$. Czyż nie mamy prawa czuć się nieco zagubieni w tym wyścigu technologicznych zmian sprawiających, że technologie tworzenia, przesyłania i zapisu informacji potrafią zmienić się kilkukrotnie w ciągu jednego pokolenia?

Naturalnym beneficjentem rewolucji technologicznej w komunikowaniu się jest edukacja. Każdy proces nauczania jest bowiem ściśle i nierozerwalnie związany z procesem komunikowania się. Rozwój mediów i technologii informacyjnych przywołuje do życia pedagogikę medialną zwaną także technologią kształcenia, szukającą odpowiedzi na pytania w trzech głównych obszarach badań: o dobór najbardziej odpowiednich narzędzi dydaktycznych (mediów, technik, technologii) do konkretnego typu i obszaru nauczania (chociażby do nauczania przedmiotów przyrodniczych lub artystycznych, do nauczania w klasie lub w domu itd.), o sens, kierunek i jakość kształcenia poprzez narzędzia i technologie informacyjne w kontekście ich dynamicznej ewolucji oraz o badanie efektywności dydaktycznej narzędzi i pomocy medialnej w różnych typach i obszarach kształcenia ${ }^{8}$.

Znana nam i opisywana w literaturze przedmiotu historia nowoczesnego kształcenia wykorzystującego media sięga Jana Amosa Komeńskiego, który sformułował zasadę poglądowości w nauczaniu i zaprezentował jej praktyczną realizację w podręczniku Orbis Pictus z roku 1658. Jak jednak wynika, chociażby z moich wcześniejszych uwag, prekursorów poglądowości, obrazowania, egzemplifikowania należy oczywiście szukać znacznie wcześniej. Sam Komeński w „Pampaedii” za prekursora poglądowości w dydaktyce uważał Platona, pisząc, że Platon radził, by dzieci zabierano na wojnę, by przyglądały się bitwom, a to w podwójnym celu: aby na ich oczach ojcowie mężniej o nie walczyli, aby dzieci uczyły się naśladować męstwo ojców"". Jednym z najważniejszych etapów w ewolucji dydaktycznego stosowania pomocy był rozwój poligrafii (i pojawienie się np. drukowanej fotografii). Jednak dodatki zwiększające możliwości nauczyciela czy podręcznika szkolnego (w postaci tzw. obudowy dydaktycznej) to również tak „oczywiste” przedmioty, jak kredki, farbki, plastelina czy w końcu najzwyklejsza tablica. O ile te pomoce są znane od dawna, to wiek XX przyniósł wielką grupę nowych, złożonych (technicznych) środków dydaktycznych, mających ścisły związek z mediami, ich przekaźnikami oraz technologią informacyjną.

\footnotetext{
${ }^{7}$ Za symboliczną datę pojawienia się „komputera dla wszystkich” uznaję światową premierę (i światową promocję) osobistego komputera Apple Macintosh w roku 1984.

${ }^{8}$ Bednarek, J. 2006. Multimedia w ksztatceniu. Warszawa: Wydawnictwo Naukowe PWN.

${ }^{9}$ Komeński, J.A. 1973. Pampaedia. Wrocław: Ossolineum. 169.
} 
Zamykając wprowadzenie historyczne można w tym miejscu przedstawić następującą tezę: każdy proces komunikacyjny, zarówno ten w wymiarze międzyludzkim i intrapersonalnym, jak i wszystkie zachowania komunikacyjne odbywające się w przestrzeni społecznej są jednocześnie procesami umieszczonymi w wymiarze dydaktycznym. Każda technika komunikacji, lokalna czy globalna, od gestu poczynając na transmisji głosu online kończąc jest jednocześnie techniką podporządkowaną uczeniu się lub nauczaniu. Każda technologia komunikacyjna jest jednocześnie technologią kształcenia. Związek obu jest nierozerwalny. Każde nasze zachowanie, reakcja, gest, słowo lub tylko jego artykulacja jest lekcją. Za Chomskym można uznać, że poznajemy i doznajemy rzeczywistość na tyle, na ile znamy język (kod), który tę rzeczywistość opisuje ${ }^{10}$, zaś za Wittgensteinem, że opisujemy granice świata, który poznajemy i doznajemy jako granice języka, którym się posługujemy ${ }^{11}$. Biorąc pod uwagę powyższe można stwierdzić, że nauczanie/uczenie się (w tym „,czytanie świata”) uzależnione jest od wszystkich dostępnych człowiekowi (ale i ptakowi z gatunku jastrzębiowatych) narzędzi komunikacji od zmysłów poczynając na cyberprzestrzeni kończąc. Przejście od komunikacji bezpośredniej do komunikacji z wykorzystaniem narzędzi jest pierwszą ludzką rewolucją komunikacyjną i edukacyjną zarazem, której odpryski w postaci komputerów i internetów dają o sobie znać do dziś. I będziemy komunikacyjnymi kuzynami ścierwnika białego rozbijającego kamieniem muszle i jaja do czasu drugiej rewolucji, gdy człowiek w procesie komunikacji przestanie posługiwać się jakimikolwiek narzędziami.

Jednym z najważniejszych zadań i funkcji dowolnego systemu edukacji jest wyposażenie ucznia (również samego siebie w procesie samokształcenia) oraz nauczyciela $\mathrm{w}$ taki system językowy (obejmujący także techniki, technologie i narzędzia) i takie kompetencje komunikacyjne, aby oba podmioty procesu kształcenia odbierały i rozumiały rzeczywistość w sposób spójny z dostrzeżeniem istniejących relacji, uwarunkowań, granic i norm. I tu właśnie ujawnia się pierwszy, najbardziej ogólny, można by rzec, filozoficzny problem, dotyczący relacji pomiędzy technologią i edukacją. Ich nieprzekraczalna niekoherentność. Biorąc pod uwagę najprostszą $\mathrm{z}$ definicji koherencji autorstwa Francisa Herberta Bradleya mówimy, że prawdziwe jest to, co jest wewnętrznie spójne (przystające do siebie, pasujące do siebie). Natomiast związek technologii i edukacji jest, co postaram się wykazać za chwilę, z założenia niespójny, a relacja,

\footnotetext{
${ }^{10}$ Chomsky, N. 1968. Language and mind. New York: Hartcourt Brace Jovanovich. Podaję za: Skrzypczak, J. 1995. „Niektóre dylematy edukacji językowej w dobie komunikacji audiowizualnej”. W: Strykowski, W. i A. Zając. (red.). Nowoczesna technika w kulturze - nauce - oświacie. Tarnów: Tarnowska Oficyna Wydawnicza WOK.

${ }^{11}$ Wittgenstein, L. 2000. Dociekania filozoficzne. Warszawa: Wydawnictwo Naukowe PWN. Podaję za: Wendland, M. 2011. Konstruktywizm komunikacyjny. Poznań: Wydawnictwo Naukowe Instytutu Filozofii UAM. 26.
} 
którą powyżej opisywałem jako relację wzajemnie powiązanych edukacji i technologii należy jednak rozpatrywać w ujęciu rozłącznym; jako edukacja versus technologia.

Edukacja była, jest i będzie w stałej nieprzystawalności pomiędzy tym, co było (w kulturze, w nauce, w sztuce) a tym, co jest tutaj i dzisiaj. O ile technologie informacyjne są $\mathrm{w}$ stałym i naturalnym procesie zmiany i rozwoju (a nawet muszą być zgodnie ze znanym prawem Moore'a) ${ }^{12}$ to edukacja jest i będzie w naturalnym stanie opóźnienia wobec nowoczesności, objawiającym się jej permanentnym kryzysem. Świat z zasady pędzi, edukacja z założenia przekazuje uczącym się jego zatrzymany w danym momencie obraz ${ }^{13}$. Co ciekawe, ów kryzys spójności i nieprzystosowanie (w tym nieprzystosowanie technologiczne) jest tak stare, jak sama edukacja. Najstarsze znane zabytki piśmiennicze (tabliczka z Tărtării oraz tabliczka z Dispilio) mają około 7000 lat ${ }^{14}$. Zaś za najstarsze świadectwo kryzysu wychowania i edukacji można uznać napisy znajdujące się na jednej z odkrytych w mieście Ur glinianych tabliczek, liczącej ok. 5000 lat. Zawiera ona taką oto inskrypcję, zapisaną pismem klinowym: „Jeszcze nigdy w historii młodzież nie była tak źle chowana, a świat nie stoczył się tak nisko" ${ }^{15}$. Warto w tym miejscu zacytować głos Marii Kwiatkowskiej-Ratajczak z Pracowni Innowacji Dydaktycznych UAM w Poznaniu, że immanentną cechą edukacji jest stałe oscylowanie między synchronią i diachronią: „Edukacja jest (...) z jednej strony czynnikiem odtwarzania kultury w kolejnych pokoleniach, $\mathrm{z}$ drugiej zaś powinna być też elementem zmiany" ${ }^{\prime 16}$. Oznacza to ciągłe napięcie między tym, co stałe i niezmienne, tym, co już w kulturze zastygło, a tym, co stanowi zmianę. Jest to stały dylemat między tym, co się już zestarzało i wymagaja usunięcia, a tym, co właśnie stało się istotnym i stałym elementem świata.

\footnotetext{
${ }^{12}$ Co jest również prozaicznym źródłem kłopotów finansowych każdego dyrektora zarządzającego instytucją edukacyjną: jak efektywnie wydać olbrzymie pieniądze na modernizację infrastruktury technologicznej dziś mając świadomość, że jutro infrastruktura ta będzie co najmniej przestarzała.

${ }^{13}$ Najłatwiej możemy ten proces prześledzić na przykładzie polonistycznych dyskusji nad kanonem lektur zalecanych uczniom szkół powszechnych.

${ }^{14}$ Zob. Zieliński, Z. 2010. Archeologia mediów.Warszawa: Oficyna Naukowa. (Wydanie niemieckie: Zieliński, Z. 2002. Archäologie der Medien. Hamburg: Rowohlt).

${ }^{15}$ Bereś, W. „Ta grzeszna wolność”. Gazeta Wyborcza, 1 lipca 2003. W ten natomiast sposób o „kryzysie” pisał przed kilkunastoma laty współczesny filozof: „Obyśmy sobie tego totalnego kryzysu nie wynarzekali: nie powozi nam się aż tak dobrze, by stać nas było na taki luksus negatywizacji i dumę z kryzysu, który przecież i tak codziennie dementuje rzeczywistość i obecną w niej obfitość nienaruszonych tradycji. Także i przede wszystkim jako nowocześni, my, ludzie, nadal pozostajemy bardziej naszymi tradycjami niż naszymi modernizacjami”. Marquard, O. 1994. Apologia przypadkowości. Warszawa: Oficyna Naukowa. 108.

${ }^{16}$ Kwiatkowska-Ratajczak, M. 2003. „Mickiewicz i Edu-Romy”. W: Sokołowski, M. (red.). Media i edukacja w globalizującym się świecie. Olsztyn: Oficyna Wydawnicza Kastalia. 85.
} 
W takim ujęciu edukacja, próbując ,gonić” świat, zmuszona jest do reformowania się. Współcześnie, w związku z ekspansją technologii we wszystkich dziedzinach życia, mamy do czynienia z przemianami w takiej skali i o tak wielkiej dynamice, że znacznie wyżej ceni się dziś zmianę i zmienność od stabilności, a kulturotwórcza rola edukacji jest bardziej utrudniona.

Edukacja (a zwłaszcza scentralizowana szkoła) jest i będzie w stałej opozycji do technologii informacyjnych, co wyraźnie dało się zauważyć w echach dyskusji z lat 90-tych XX wieku, dotyczących negatywnych zjawisk związanych z wpływem mediów i multimediów na dzieci i młodzież. Pełne troski głosy metodyków, pedagogów, psychologów, medioznawców, mówiące o medialnych uzależnieniach (tym razem nie zapisane na glinianych tabliczkach tylko wydrukowane), wzroście agresji, apatii komunikacyjnej wśród dzieci i młodzieży zmuszały do stawiania pytań o to, jak w świecie technologicznych gadżetów, multimediów i wirtualnych doznań należy definiować główne cele formacyjne szkoły i, w jaki sposób należy myśleć o technologii, by w znacznie szerszym stopniu wykorzystywać jej zalety, unikając zagrożeń. Pytania te, formułowane w latach dziewięćdziesiątych, nadal są aktualne, zaś sama dyskusja o szkodliwym wpływie mediów cyfrowych na psychikę dzieci i młodzieży wróciła w kolejnej odsłonie po publikacji wyników tez dotyczących przemian zachodzących w mózgu na skutek silnych bodźców komunikacyjnych autorstwa Marka Prenskyego z 2001 roku $^{17}$ i potwierdzonych w 2007 roku przez badania Garry'ego Smalla i Gigi Vorgana Uniwersytetu Kalifornijskiego w Los Angeles ${ }^{18}$.

Przechodząc do części analitycznej chciałbym się skupić na problemie efektywności (skuteczności) dydaktycznej wybranych narzędzi w trzech różnych badaniach dotyczących trzech różnych wariantów kształcenia i trzech strategii wprowadzenia nowoczesnych technologii informacyjnych $w$ obszar nauczania/uczenia się. Pierwsze z badań jest całkiem nowe, pochodzi bowiem z roku 2014 i dotyczy zjawiska edukacyjnego dość już dziś powszechnego - nauczania języka obcego (tutaj języka angielskiego) przez narzędzie wideo online. Autorka badania dr Marta Koszko z Katedry Ekokomunikacji Wydziału Neofilologii UAM w Poznaniu skupia się na analizie poziomów przekazu komunikatu werbalnego i niewerbalnego w trakcie nauczania online poprzez narzędzie Skype ${ }^{19}$.

Badaczka wykazała, że przekaz edukacyjny tego typu jest uboższy komunikacyjnie od przekazu tradycyjnego i umieściła najważniejsze różnice w układzie

\footnotetext{
${ }^{17}$ Prensky, M. 2001. „Digital natives, digital immigrants”. On the Horizon 9(5). 1-6.

${ }^{18}$ Small, G. i G. Vorgan. 2008. iBrain: surviving the technological alteration of the modern mind. New York: William Morrow.

${ }^{19}$ Koszko, M. (w druku). „Charakterystyka wirtualnego środowiska komunikacyjnego na podstawie analizy zachowań werbalnych i niewerbalnych nauczycieli i uczniów w kontekście glottodydaktyki”. I Konferencja ekolingwistyczna pt. „Motywy ekolingwistyczne - w stronę ekoglottodydaktyki (MOTEK)”. Poznań: UAM, 2014.
} 
tabelarycznym. W badaniu nie postawiono pytania o efektywność dydaktyczną analizowanej formy kształcenia w stosunku do metod i technik nauczania języka „na żywo" (nie było to zresztą, jak twierdzi dr Koszko, przedmiotem jej zainteresowania). Nie można w żadnym wypadku wykluczyć, że efektywność tej formy jest wysoka (o czym zresztą świadczy sam fakt, że metoda ta znajduje wielu chętnych), warto jednak zastanowić się nad różnicami między umiejętnościami ucznia zaangażowanego w lekcję w sprofilowanej przestrzeni dydaktycznej (np. w klasie), a kompetencjami komunikacyjnymi ucznia mającego kontakt z dwuwymiarowym ekranem monitora komputerowego. Pytanie, które w tym przypadku wydaje się zasadne, brzmi: czy technika komunikacji, z założenia ograniczona i uboższa w przekazie, może być komplementarnym narzędziem dydaktycznym umożliwiającym osiąganie równorzędnych efektów dydaktycznych takich, jakie uzyskuje się poprzez metody ,tradycyjne”? Jest to pytanie otwarte, tak samo, jak kwestia miejsca tego typu nauczania w całym procesie kształcenia językowego.

Zaprezentowane badanie koncentrowało się na obserwacji kształcenia podstawowych umiejętności komunikacyjnych, jakie nabywa się w trakcie nauczania języka obcego. Drugie badanie skupia się na odczytywaniu/rozumieniu tekstów na znacznie wyższym, bo symbolicznym poziomie. Eksperyment badawczy przeprowadził autor niniejszego tekstu w roku $2008 \mathrm{w}$ poznańskich liceach, obserwując interpretację filmowego, symbolicznego tekstu kultury w dwóch wariantach: $\mathrm{w}$ przestrzeni szkoły oraz $\mathrm{w}$ domowej przestrzeni wirtualnej. $\mathrm{W}$ obu wariantach uczniowie klas licealnych, w trakcie zajęć języka polskiego nad obowiązkową lekturą „Roku 1984” George'a Orwella, analizowali dodatkowo zaproponowany kontekst kulturowy, którym był film „Olimpia” Leni Riefenstahl. W pierwszym wariancie ,szkolnym” uczniowie czytali lekturę w domu, a następnie oglądali film Riefenstahl w klasie wraz z nauczycielem, który wprowadzał dodatkowe komentarze, konteksty, wyjaśnienia. W drugim wariancie uczniowie po przeczytaniu lektury otrzymali płytę DVD, zawierającą specjalnie zakomponowaną lekcję multimedialną z filmem oraz bogatymi i różnorodnymi medialnie komentarzami, kontekstami oraz ćwiczeniami interaktywnymi.

Zadaniem kończącym pracę każdej z grup było napisanie pracy zatytułowanej „Od idei do ideologii - scharakteryzuj mechanizm przekształcania przez reżimy totalitarne idei w ideologię na podstawie znanych sobie tekstów kultury". Nauczyciele zobowiązani zostali do zwrócenia szczególnej uwagi na zaprezentowaną w filmie kwestię relacji między kulturą antyczną (wraz z jej ideami) a III Rzeszą (wraz z jej ideologią). Właściwe poprowadzenie zajęć miało umożliwić uczniom zrozumienie zastosowanego przez Riefenstahl propagandowego mechanizmu, a tym samym ułatwić napisanie pracy domowej.

Założono, że sugestywność i atrakcyjność Olimpii powinna znacząco wpłynąć na pojawienie się kontekstów nazistowskich oraz zaowocować próbą obja- 
śnienia mechanizmu propagandowego za pomocą obecnej w filmie relacji kultura antyczna - III Rzesza. Częstotliwość pojawiania się określonych nawiązań do Olimpii oraz generalnie nawiązań do problematyki nazistowskiej miała stanowić ważny aspekt ilościowy eksperymentu, mówiący o stopniu efektywności mediów (w strategii szkolnej) i multimediów (w strategii domowej). Aspekt ilościowy nie był jedynym kryterium oceny prac pisemnych, równie istotna była analiza ich jakości. W tym przypadku trudno wyzbyć się subiektywizmu, dlatego w badaniu skupiono się wyłącznie na najbardziej wyrazistych elementach, które miałyby informować o sposobie odebrania tematu oraz o formie powiązania go z filmem Leni Riefenstahl, a tym samym o efektywności nośnika medialnego. się szczególną uwagę zwrócono na formy funkcjonowania „Olimpii” jako kontekstu wyjaśniającego mechanizm przekształcania idei w ideologię. Prace uczniów podzielono na trzy poziomy przywołania kontekstu: poziom zerowy, bezpośredni i pogłębiony. Dla uzyskania dokładniejszych wyników przebadano po trzy grupy uczniów w każdym wariancie.

Tabela 1. Procent odwołań do nazizmu oraz Olimpii w pracach uczniów grup ,szkolnych” (wyniki ilościowe)

\begin{tabular}{|c|c|c|c|}
\hline Grupa & A1 & B1 & C1 \\
\hline $\begin{array}{l}\text { Procent prac zawierających nawiązania do nazi- } \\
\text { zmu w stosunku do ogółu prac }\end{array}$ & $85 \%$ & $79 \%$ & $89 \%$ \\
\hline
\end{tabular}

Tabela 2. Procent odwołań do nazizmu lub Olimpii w pracach uczniów grup „domowych” (wyniki ilościowe)

\begin{tabular}{|c|c|c|c|}
\hline Grupa & A2 & B2 & C2 \\
\hline $\begin{array}{l}\text { Procent prac zawierających nawiązania do nazizmu } \\
\text { lub Olimpii w stosunku do ogółu prac }\end{array}$ & $68 \%$ & $17 \%$ & $15 \%$ \\
\hline
\end{tabular}

Porównując jakość prac grup ,szkolnych” do „domowych” należy stwierdzić, że wyzwanie komunikacyjne wprowadzone przez wariant medialny zaprezentowany przez program komputerowy okazał się zdecydowanie zbyt trudny, a tym samym nieczytelny dla samodzielnie pracujących z nim uczniów. Technologia informacyjna doskonale sprawdza się $\mathrm{w}$ realizowanej od tysiącleci poglądowości w naukach przyrodniczych, ścisłych czy historii, jednak w przypadku kształcenia kompetencji komunikacyjnych daje się zaobserwować następującą prawidłowość: wraz ze wzrostem komplikacji komunikacyjnych, interpretacyjnych oraz stopniem skomplikowania przekazu efektywność dydaktyczna technologii informacyjnych spada, zaś efektywność dodatkowo się zmniej- 


\section{sza, jeśli narzędzie z założenia oferuje przekaz ograniczony w przekazie lub stosowany jest jako jedyne narzędzie dydaktyczne ${ }^{20}$.}

Multimedia, w zakresie potęgi obrazowania, świetnie wpisują się w obszar nauk przyrodniczych, ale czy i w tym przypadku nie występują utrudnienia? Trzecie prezentowane badanie (a raczej wyniki serii badań) są najstarsze z całej grupy i pochodzą z lat dziewięćdziesiątych XX wieku. Przeprowadziła je grupa badaczy z Zakładu Dydaktyki Chemii UAM w Poznaniu z profesorami Hanną Gulińską i Andrzejem Burewiczem na czele. Zespół pod kierunkiem wymienionych wyżej badaczy opracował (a część wydał) kilkadziesiąt różnego rodzaju pomocy multimedialnych, przeprowadził setki (jeśli nie tysiące) godzin badań efektywności narzędzi na wszystkich poziomach edukacji. Poznańscy dydaktycy chemii potwierdzili jednoznacznie wysoką efektywność technik obrazowania z wykorzystaniem technologii multimedialnych w nauczaniu chemii. W oparciu o swoje badania wymieniony zespół stworzył pierwszy i jedyny, jak dotąd, w historii multimedialny podręcznik szkolny wydany przez renomowane wydawnictwo i wprowadzony do szkół pod tytułem „Multimedialny Podręcznik Chemii dla Gimnazjum" "21. Podsumowaniem wieloletnich badań nad multimedialnością w nauczaniu chemii jest publikacja Hanny Gulińskiej zatytułowana „Strategie multimedialnego kształcenia chemicznego,"22.

Mimo jednoznacznie pozytywnych efektów dydaktycznych oraz doskonałej recepcji programów multimedialnych uważny czytelnik, wśród wyników badań, znajdzie kilka relacji zbieżnych z opublikowanymi 10 lat później uwagami Smalla i Vorgana. Cytuję za Hanną Gulińską: „Zauważono (w czasie badań) pewne zakłócenia w procesie komunikowania na drodze medialnej" i dalej: „Praca z wykorzystaniem programów multimedialnych może prowadzić do różnego rodzaju niepożądanych zachowań osób uczących się (...). Należą do nich nadpobudliwość psychoruchowa (ujawniająca się złą koncentracją uwagi, osłabieniem procesów analizy i syntezy, osłabioną zdolnością planowania i wzmożoną emocjonalnością) oraz różnego rodzaju zahamowania (objawiające się utrudnionym odbiorem informacji, wolniejszym sposobem myślenia i porozumiewania się. Pojawiają się wśród nich zachowania charakterystyczne dla pracy z komputerem, a wśród nich, zwłaszcza w przypadku indywidualnego korzysta-

\footnotetext{
${ }^{20}$ Wobalis, M. 2011. Multimedia w nauczaniu polonistycznym. Poznań: Wydawnictwo „Poznańskie Studia Polonistyczne". 120-140.

${ }^{21}$ Gulińska, H. i A. Burewicz. 2000. Chemia z elementami ekologii. Część 1. Podstawy chemii. Multimedialny podręcznik dla gimnazjum. Warszawa: WSiP. Gulińska, H. i A. Burewicz. 2001. Chemia z elementami ekologii. Część 2. Typy zwiazków nieorganicznych Multimedialny podręcznik dla gimnazjum. Warszawa: WSiP. Gulińska, H. i A. Burewicz. 2002. Chemia z elementami ekologii. Czesść 3. Wegiel i jego związki Multimedialny podręcznik dla gimnazjum. Warszawa: WSiP.

${ }^{22}$ Gulińska, H. 1997. Strategia multimedialnego ksztatcenia chemicznego. Poznań: Wydawnictwo Naukowe UAM.
} 
nia z komputera, niesubordynacja, polegająca na trudnym do opanowania dążeniem do przeglądania wszystkiego, co w danym momencie znajduje się na dysku komputera, a w przypadkach skrajnych, kopiowania niektórych zbiorów bez wiedzy prowadzącego" ${ }^{\text {"23 }}$. W innym miejscu, w trakcie opisu efektywności zapamiętywania materiału nauczania, badaczka zwraca uwagę na ciekawe zjawisko polegające na zapamiętaniu przez część uczniów wyłącznie faktu pracy/zabawy z komputerem, a nie treści nauczania przekazanych przez narzędzie.

Idąc tym tropem w 2002 roku piszący te słowa przeprowadził własne obserwacje multimedialnego podręcznika chemii do gimnazjum $w$ grupie dzieci ze szkoły w Swarzędzu. Uczniowie pracowali z lekcją multimedialną zawierającą trójwymiarowe, przestrzenne animacje związków i reakcji chemicznych. Dzieci oglądały obracające się atomy węgla, model kwasu siarkowego, kilkuminutową reakcję łańcuchową rozszczepienia uranu. Animacje 3D zostały przygotowane w ten sposób, że po założeniu specjalnych okularów (dołączonych do podręcznika) uczeń mógł oglądać wybrane animacje kilka centymetrów przed ekranem monitora komputerowego. Do każdej animacji opracowana została odpowiednia ścieżka lektorska omawiająca rozgrywające się przed ekranem zjawiska chemiczne.

Dzisiaj w dobie kin i telewizorów 3D obrazy tego typu wrażenia nie robią, jednak w 2002 roku obserwacja reakcji dzieci na trójwymiarowe animacje była niezwykle interesująca. Uczniowie byli niezwykle poruszeni i pobudzeni, reagowali bardzo żywo i komentowali animacje. Niektórzy próbowali chwytać obracające się cząsteczki. Z wywiadów przeprowadzonych tuż po zajęciach wynika, że dzieci doskonale pamiętały wygląd (budowę, kolory) i ruch cząstek, nie potrafiły jednak ich odpowiednio nazwać. W większości przypadków umknął także komentarz dołączony do animacji, który albo został zagłuszony przez ożywione reakcje i rozmowy, albo w ogóle nie został przez uczniów zarejestrowany. Poproszono nauczycielkę, by nie robiła powtórki i nie poświęcała dodatkowego czasu na ponowne utrwalenie materiału. W wywiadach przeprowadzonych po dłuższym czasie dzieci w większości pamiętały już tylko to, że na lekcji chemii założyły śmieszne, kolorowe okulary i coś kręciło się bardzo efektownie przed ekranem komputera.

\section{Podsumowanie}

Technologie multimedialne umiejętnie wykorzystywane w dydaktyce pozwalają na osiąganie doskonałych efektów. Rozwijają, bawią, uczą, pomagają zapamiętywać trudne informacje, umożliwiają przeprowadzanie skomplikowa-

\footnotetext{
${ }^{23}$ Tamże, 292-293.
} 
nych eksperymentów lub doświadczeń w domowym fotelu. Celem tego artykułu nie było oczywiście podważanie niepodważalnych i wielokrotnie udowodnionych eksperymentów. Wysokiej efektywności technologii informacyjnych w edukacji przyrodniczej poświęcona jest wymieniana wyżej „Strategia multimedialnego kształcenia chemicznego", w nauczaniu humanistycznym mamy „Ekranowego czytelnika” Anieli Książek-Szczepanikowej ${ }^{24}$, książkę opisującą ciekawe, rozwijające i twórcze działania dydaktyczne z komiksem i filmem. Poświęcone są temu także „Multimedia w nauczaniu polonistycznych” pióra autora tego artykułu. Technologia i edukacja zawsze szły obok siebie i nic tego nie zmieni. Są na siebie skazane. Warto jednak mieć w pamięci zaprezentowane wyżej zastrzeżenia, zwłaszcza jednak zadbać o to, by w karuzeli zmieniających się gadżetów jedynym pozostającym w pamięci ucznia efektem działania nowoczesnych technologii nie stało się wspomnienie wyłącznie tego, że „coś się gdzieś w czymś fajnie kręciło".

\section{Bibliografia}

Bednarek, J. 2006. Multimedia w ksztatceniu. Warszawa: Wydawnictwo Naukowe PWN.

Briggs, A. i P. Burke. 2010. Społeczna historia mediów. Warszawa: Wydawnictwo Naukowe PWN.

Debray, R. 2010. Wprowadzenie do mediologii. Warszawa: Oficyna Naukowa.

Dijk, J.V. 2010. Społeczne aspekty nowych mediów. Warszawa: Wydawnictwo Naukowe PWN.

Eskarpit, R. 1991. Rewolucja książki. Warszawa: PWN.

Gulińska, H. 1997. Strategia multimedialnego ksztatcenia chemicznego. Poznań: Wydawnictwo Naukowe UAM.

Kulczycki, E. i M. Wendland. (red.). 2012. Komunikologia. Teoria i praktyka komunikacji. Poznań: Wydawnictwo Naukowe Instytutu Filozofii UAM.

McLuhan, E. i F. Zignore. (red.). 2001. McLuhan. Wybór tekstów. Poznań: Zysk i S-ka.

Spitzer, M. 2013. Cyfrowa demencja. Słupsk: Dobra Literatura.

Vandendorpe, Ch. 2008. Od papirusu do hipertekstu. Esej o przemianach tekstu i lektury. Warszawa: Wydawnictwa Uniwersytetu Warszawskiego.

Wendland, M. 2011. Konstruktywizm komunikacyjny. Poznań: Wydawnictwo Naukowe Instytutu Filozofii UAM.

Wobalis, M. 2010. „E-rzeczywistość czy e-nierzeczywistość”. Polonistyka 11. 12-18.

Wobalis, M. 2011. Multimedia w nauczaniu polonistycznym. Poznań: Wydawnictwo „Poznańskie Studia Polonistyczne". 120-140.

Zieliński, Z. 2010. Archeologia mediów. Warszawa: Oficyna Naukowa.

\footnotetext{
${ }^{24}$ Książek-Szczepanikowa, A. 1996. Ekranowy czytelnik - wyzwanie dla polonisty. Szczecin: Wydawnictwo Naukowe Uniwersytetu Szczecińskiego.
} 